\title{
The Lesson Plans Of History Teachers Based On The 2013 Curriculum At Public Senior High School 1 Of Jember
}

\author{
Agusningrum $^{1}$, Bambang Soepeno ${ }^{2}$, Sumardi $^{3}$ \\ ${ }^{1}$ University of Jember, Faculty of Teacher Training and Education \\ Kalimantan Street 37, Jember 68121, Indonesia \\ ${ }^{2}$ University University of Jember, Faculty of Teacher Training and Education \\ Kalimantan Street 37, Jember 68121, Indonesia \\ ${ }^{3}$ University of Jember, Faculty of Teacher Training and Education \\ Kalimantan Street 37, Jember 68121, Indonesia
}

\begin{abstract}
:
This article is intended to describe the lesson plans developed by History subject teachers at SMA Negeri 1 Jember. The design of this research was interactive qualitative with the ethnographic design of case studies, assessment based on the analysis of interview results, observations, documents, and questionnaires. The data source under investigation was both primary and secondary data. The results of this research showed that at the lesson planning stage, the History teachers who were members of the MGMP school team developed independent lesson plans in accordance with the class level they taught. The preparation of lesson plans was carried out at the beginning of the semester or new academic year during in-house training and on-house training. The analysis of the lesson plans components showed that the lesson plans developed by each History teacher were in accordance with the provisions. The average score of 89 lesson plans was 131 or $73 \%$. The composition of the lesson plans components referred to the process standard in The Regulation of Ministry of Education and Culture No. 81A of 2013, The Regulation of Ministry of Education and Culture No. 103 of 2014, and The Regulation of Ministry of Education and Culture No. 22 of 2016.
\end{abstract}

Keywords: Lesson plan component, 2013 curriculum, History subject

\section{Introduction}

The implementation of History learning at the primary and secondary education level has a linear position with the 2013 curriculum. This is related to the objectives of the History subject and the 2013 curriculum which have similarities. History subject is designed to develop critical thinking skill and students' character that are manifested in attitudes such as historical awareness, nationalism, patriotism, and humanities insight [1] and it is the same as the 2013 curriculum that designed to produce educational output which characterized by high intellectual abilities and strong character. Both History learning and the 2013 curriculum are projected to make students have moral, academic, and skill competence.

Ironically, in the implementation of History learning and the implementation of the 2013 curriculum has been tainted with various problems that emerged, including in the aspect of the preparation of lesson plans. While the lesson plan is an important part in determining the achievement of the objectives of the implementation of learning. Through lesson plan the teacher can think of the lessons to be implemented, the difficulties that arise during the learning activities, and efforts to overcome the predicted problems [2]. Teachers can organize all learning facilities and infrastructure, time, and content of learning as an effort to achieve the learning objectives.

The existence of lesson plan can help teachers to realize the programmed learning activities, so learning objectives are achieved optimally. The development of lesson plan must be carried out properly, so it is effective and efficient in the implementation of learning and the achievement of learning objectives. In the preparation of the lesson plan, the teacher must pay attention to the principles 
of developing lesson plan and provisions concerning process standards regulated through the Regulation of Ministry of Education and Culture. In the 2013 curriculum, the latest Regulation of Ministry of Education and Culture which regulates the process standard is the Regulation of Ministry of Education and Culture No. 22 of 2016. Therefore, in the development of lesson plan the teacher must pay attention to the lesson plan components based on the regulations, which consist of at least five main components in the lesson plan, namely learning objectives, learning materials, learning methods, learning media, and assessment.

From the descriptions above, the purpose of this article is to describe the lesson plan that was developed by the teachers of History subject at SMA Negeri 1 Jember. The description includes nine components of lesson plan as stipulated in the Regulation of Ministry of Education and Culture No. 22 of 2016, starting from the components of identity of subject to the assessment plan of learning outcomes. The contents of this article are part of the results of research on the implementation of History learning based on the 2013 curriculum at SMA Negeri 1 Jember.

\section{Research Method}

The design of this research was qualitative which applied interactive qualitative research method with ethnographic case study. The data collection technique used was purposeful sampling technique with homogen sampling strategy [3] and the data collection used interviews, observations, documents, and questionnaires. The sources of data included informants, observation results, documents, and respondents. The data analysis techniques used interactive model that which is iterative included data reduction, data presentation, and conclusion drawing [4]. The observation techniques of research results used credibility, transferability, dependability, and confirmability methods [5].

\section{Research Result}

In this study, 89 lesson plans of History subject for both odd and even semesters were investigated, covering grades X, XI, and XII in both Science and Social Science classes. The details are as listed in the following table.
Table 1: The Details of Lesson Plans of History Subject

\begin{tabular}{|l|l|c|c|}
\hline \multirow{2}{*}{$\begin{array}{c}\text { Grade/ } \\
\text { Teacher (G1) }\end{array}$} & \multicolumn{1}{c|}{ Group } & \multicolumn{2}{c|}{ Semester } \\
\cline { 3 - 4 } & & Odd & Even \\
\hline X/G1 & $\begin{array}{l}\text { Science/Social } \\
\text { Science }\end{array}$ & 5 & 7 \\
\hline X/G3 & $\begin{array}{l}\text { Science/Social } \\
\text { Science }\end{array}$ & 5 & - \\
\hline XI/G2 & Science & 10 & 13 \\
\cline { 2 - 4 } & Social Science & 9 & 11 \\
\hline XII/G3 & Science & 10 & 10 \\
\cline { 2 - 4 } & Social Science & 6 & 3 \\
\hline
\end{tabular}

The results of this research indicated that there was an arrangement of lesson plan formats that were not in accordance with the provisions of the standard process in the Regulation of Ministry of Education and Culture No. 22 of 2016. The composition of the lesson plan format still referred to the Regulation of Ministry of Education and Culture No. 81A of 2013 and the Regulation of Ministry of Education and Culture No. 103 of 2014. The results of the analysis of the suitability of each lesson plan component against the regulation of the drafting of lesson plan based on the process standards listed in the Regulation of Ministry of Education and Culture No. 22 of 2016, of 89 lesson plan indicated that 66 or $74 \%$ of the lesson plans were rated between 113 and 146. In addition, 23 or $26 \%$ of the lesson plan were scored between 147 and 180 with an average score of 131 lesson plans or $73 \%$ of the total lesson plans. It means that the lesson plans developed by each History teacher were in accordance with the provision. When compared with the lesson plan component suitability level criteria, the suitability level of each component in each lesson plan developed by teachers 1,2 and 3 met the criteria of good and very good.

\section{Discussion}

The Regulation of Ministry of Education and Culture No.22 of 2016 concerning the standard of primary and secondary education processes states that learning devices are part of learning planning that refers to content standard. One part of the learning planning is the preparation of lesson plan. According to the guideline provisions for the 2013 curriculum implementation, the preparation of the lesson plan together with other learning tools must be carried out at the beginning of the semester or the beginning of the academic year, both individually and/or collectively through the school MGMP which 
supervised by the school or inter-school or interregional MGMP which were coordinated and supervised by the education supervisor. Each component listed in the lesson plan must be in accordance with the process standard set out in the Regulation of Ministry of Education and Culture No. 22 of 2016 or the latest regulation on process standard. Based on the Regulation of Ministry of Education and Culture, the discussion focused on the main components that must be in the lesson plan. These components include objectives, materials, methods, media, and evaluation of learning outcomes.

For the preparation of the lesson plan, the institutional policy requires the teacher to prepare the lesson plan and the entire learning tool in the new academic year. After the class promotion test or Ujian Kenaikan Kelas (UKK) or semester end assessment or Penilaian Akhir Semester (PAS) of even semester, each teacher including the history teacher followed the in-house training program (IHT) for 3 days to compile the learning tools. During the IHT program, each history teacher gathered in one MGMPS team compiled lesson plans and other learning device components for one academic year. The technical process was each history teacher compiled lesson plans and other learning device components for each class. In addition to the IHT program, the preparation of the lesson plan and other learning tools also through onhouse training (OHT) program. OHT is a special program for teachers who have not been able to complete lesson plan work during the IHT program.

The completion of the lesson plan and the learning tools of each history teacher for one year was carried out in stages at the beginning of the semester. Of the three history teachers, only teacher 1 who completed the lesson plan and learning tools every semester in full and right at the beginning of the semester. The teacher 1 who taught history subject in grade XII and one class in grade $\mathrm{X}$ completed the preparation of the odd semester and even semester lesson plans for both Science and Social Science groups at the beginning of each semester. Teacher 2 who taught grade XI of both Science and Social Science groups still used lesson plans and learning tools of the previous year for each semester. Whereas teacher 3 who taught history subject in grade $\mathrm{X}$ only completed the preparation of lesson plans and learning tools for the odd semester only. The lesson plan and other learning tools for even semester had not been resolved, even until the research took place, teacher 3 explained that he had not had time to complete the lesson plans for the even semester. The lesson plans of odd semester along with other learning tools were signed by the principal in July 2016 without any dates.

In relation to the composition of lesson plan components, in certain lesson plans there was a composition of components that were not in accordance with the provisions of the Regulation of Ministry of Education and Culture No. 22 of 2016. There were components that were not listed in the lesson plan, namely learning objectives. This was acknowledged by teacher 1 that the previous lesson plan component composition did not include the learning objectives because it still referred to the old Regulation of the Ministry of Education and Culture. The old lesson plan only included basic competencies and indicators of achievement of competencies. The process of adjusting the composition of lesson plan components was done by the teacher on the documents that were still stored on the laptop individually. Therefore, the composition of the components in each lesson plan of each class that had been printed was different from that in the Regulation of Ministry of Education and Culture No.22 of 2016. Such reality indicated that history teachers were still less responsive to changes in regulations related to the implementation of the 2013 curriculum, specifically the Regulation of Ministry of Education and Culture that regulates the process standards.

\subsection{Learning Objective}

Learning objectives are a form of embodiment of national education goals that are actualized through the learning process. Teachers must be observant and pay attention to the provision in formulating the learning objectives. Based on the Regulation of Ministry of Education and Culture No. 22 of 2016 concerning the process standards, learning objectives must comply with the needs of basic competence achievement and the students' leaning loads by considering the lesson hours and using observable operational verbs including aspects of attitudes, knowledge, and skills. In addition, the formulation of learning objectives should include aspects of audience, behavior, condition, and degree $(\mathrm{ABCD})$ or at least include aspects of audience and behavior (AB). The formulation of learning objectives also includes all basic competencies or formulated per meeting.

The analysis results of the component analysis of the formulation of the learning objectives indicated that the teacher in formulating the learning 
objectives did not cover the entire basic competence as well as the indicators of achievement of competencies in KI-1, KI-2, KI-3, and KI-4, even certain lesson plan did not include the learning objectives component because it referred to the Regulation of Ministry of Education and Culture No. 103 of 2014. Besides the lesson plans for the odd and even semesters of grade XI of Social Science, the formulation of learning objectives in each lesson plan only included one basic competence from KI-3 or aspects of knowledge and two basic competences from KI-2 and KI-3. The lesson plans that included learning objectives on aspects of knowledge were only those devoted to grade $\mathrm{X}$ in the odd semester that created by teacher 1,8 lesson plans for grade XI of Science program for the odd semester and for grade XII of Social Science program for the even semester. Moreover, the lesson plans which included learning objectives on aspects of attitudes and knowledge were those designed for grade $\mathrm{X}$ in the odd semester created by teacher 1 . There were also 2 lesson plans for grade XI of Science program for the odd semester.

The formulation of learning objectives did not yet cover the whole $\mathrm{ABCD}$ aspects. Each formulation of learning objectives only covered aspects of $\mathrm{ABC}$ or AB. Of course, this was still in accordance with the regulation that at least the formulation of learning objectives consisted of aspects of the audience or students and behavior [6]. Although ideally in the formulation of learning objectives must contain elements of students, the observable behavior must meet the requirements for the realization of behavior and acceptable performance levels [7].

From the aspect of the operational verb, teachers had used a variety of operational verbs in each of the learning objective listed in the lesson plans. In the aspect of knowledge, teacher 1 used the operational verb "analyzing" in the grade X lesson plans for the odd semester and "understanding", "explaining", "describing", and "analyzing" in the grade XII of Science program lesson plan for second semester. By contrast, teacher 3 used the operational verb "discussing", "explaining", and "analyzing" as the aspects of knowledge. In the aspect of attitude, teachers 1 and 3 used the operational verb "showing". Teacher 2 in the lesson plan for grade XI used the operational verb "explaining", "searching", "discussing", "finding", "analyzing", and "linking" as the aspects of knowledge. The attitude aspect used the operational verb "showing". The skill aspect of using operational verb "composing", "searching", "observing", "formulating", "making", "gathering", "proving", "presenting", "connecting".

In addition, there was the use of the operational verb in learning objectives that were less measurable or over the operational verb in basic competence. For example, the objective of learning aspects of knowledge in one of the lesson plans for grade $\mathrm{X}$ designed by teachers 1 and 3 used operational verb "analyzing" or at the level 4 of cognitive abilities (C4), while operational verb in the basic competence was "understanding" or at the level 2 of cognitive abilities (C2). In one lesson plan for grade XI of Science program, the learning aspects used operational verb that could not be measured, namely "evaluating". In one lesson plan for grade XI of Social Science program, the learning objectives of the attitude aspect used the operational verbs which were not measurable, namely "living" and "developing". The use of the operational verb in learning objectives both lower and higher than the required basic competencies were assumed to have an impact on the effectiveness of the History learning process. In addition, the use of operational verbs that were not measurable would result in teachers experiencing difficulties in the preparation of assessment instruments. The learning objectives were the end of the implementation of the learning process which was the control in determining the quality of learning [6].

The use of the operational verbs in the formulation of learning objectives showed the ability or behavior that was expected to emerge and be trained in students after participating in learning activities. Referring to Bloom's taxonomy, the learning objectives formulated by each teacher on aspects of knowledge were equivalent to cognitive abilities of understanding level (C2), applying (C3), and analyzing (C4). On aspects of attitudes, the learning objectives were equivalent to level 3 of affective abilities or values embraced (self-worth), and in aspects of skills the objectives were equivalent to level 1 of psychomotor ability or perception, 2 or readiness, and 3 or directed reactions [8].

\subsection{Learning material}

The components of learning material in the lesson plan are the content of subjects that contained knowledge, values, and skills developed from various learning resources to achieve learning objectives. The development of subject matter must pay attention to the syllabus, basic competencies in KI-3 and KI-4, contextual, and integrating the potential around the student's environment. The aim 
of the students was to obtain competence from the material learned during the learning activities [9].

The results of the analysis of the learning material components listed in the lesson plan showed that the formulation of each teacher's learning material was not fully relevant to the regulation. Overall, learning material was in accordance with the main material listed in the syllabus and in accordance with the basic competence of KI-3 and KI-4, but in certain lesson plans there were no materials that described the indicators of achievement of competencies that referred to the two basic competences. For example, in 1 lesson plan for grade $\mathrm{X}$ of the odd semester designed by teacher 3, 1 lesson plan for grade $\mathrm{X}$ of the even semester designed by teacher 1, 4 lesson plans for grade XI of Science program of the odd semester, 1 lesson plan for grade XI of Social Science program of the even semester, 5 lesson plans for grade XII of Science program of the odd semester, and 1 lesson plan for grade XII of Science program of the even semester. In addition, there was the development of material in the lesson plan which did not distinguish the aspects of facts, principles, concepts, and procedures both in general and in particular parts of the four aspects. For example, in the teacher's lesson plan for grade $\mathrm{X}$ of the odd semester, the components of the learning material in the whole lesson plan were written in bullet points with no more than one paragraph elaboration and did not distinguish between facts, principles, concepts, and procedures. In other lesson plan components, the learning materials were written in the form of points according to indicators of achievement of competencies without explaining the material description, but distinguished between facts, principles, concepts, and procedures. This was found in lesson plan for grade $X$ of the even semester designed by teacher 1 , lesson plan for grade XI of Social Science of the odd semester, lesson plan for grade XI of Science program of the even semester, and lesson plan for grade XII of Science program and Social Science program of the odd semester. In the grade XII of Social Science, the lesson plans for the even semester, the components of learning material were only written down with the main material learned without the elaboration of the submain material or items that reflected indicators of achievement of competencies and differentiated between facts, principles, counseling and procedural.

The teacher had not integrated the learning material with the historical events or historical relics that were in the environment around the students even though it was relevant to basic competencies, except in lesson plan 5 and 6 for grade XII of Science program of the odd semester. In this lesson plan, the teacher had integrated learning material with local potential, namely Moch. Sroedji. Meanwhile, in lesson plan 1 and 2 for grade $X$ of the odd semester, which focused on basic competence related to discussing relics of ancient History had not included ancient historical relics in the local area. In lesson plan 11 and 12 for grade XI of Science program, there was no integration of the material of Jember people's resistance led by Lt. Col. Moch. Sroedji even though the basic competence was related to the material of popular resistance after Indonesia's independence. Lesson plan 4 for grade XII of Science program of the odd semester discussed the role of national and regional leaders in maintaining the independence. The teacher also had not specified the figures of Jember and the surrounding area at that time.

This illustrated that the History teachers had not yet realized the urgency of learning material relating to the mastery of students' competencies. The main points of learning material that students learnt were a means of achieving basic competencies assessed using assessment instruments that were prepared based on indicators of achievement of competencies [10]. Learning materials needed to be identified as to whether these had included facts, principles, concepts, and procedures. This identification will facilitate teachers in guiding students to achieve the expected competencies through learning materials. Integrating historical events or pre-History era and historical cultural heritage in the student's environment will help teachers foster a sense of belonging and awareness to preserve the historical relics that are in the local area of the students. Teachers must have adequate competency related to their disciplines, in this case is History, in order to be able to develop learning material [11] and distinguish the types of historical materials, be it fact, principle, concept, and procedure [12].

\subsection{Learning method}

The use of appropriate learning methods in learning activities will help students achieve learning objectives effectively and efficiently. The 2013 curriculum which is based on constructivist principles with a scientific approach requires teachers to plan the use of students-centered learning method. Learning methods should activate students and place students as subjects in learning activities.

The results of the component analysis of the learning methods listed in the lesson plan showed 
that each History teacher had planned the use of constructivist learning models with learning methods that supported the use of learning models. The choice of learning methods as tailored to the characteristics of students and learning material. Teacher 1 planned to use more varied learning methods when compared to the other two teachers. The learning models planned by the teacher included discovery learning, inquiry learning, problem based learning with jigsaw cooperative learning strategies, think pair and share, and group investigation, as well as learning methods encompassing discussion, question and answer, assignment, and lecture. In the lesson plan for grade XII of Social Science for the even semester, although the teacher did not specify the learning model used, the choice of learning methods planned the use of role play, social drama, and question cards.

Unlike teacher 1 , teacher 2 and teacher $3 \mathrm{did}$ not plan a lot on the use of varied learning models and methods. Teacher 2 planned to use the same learning model and method in each learning activity. The teacher planned the use of problem solving/problem based learning and discovery learning models with cooperative learning strategies that used various methods encompassing discussion, question and answer, lectures, and assignments. The learning method plan listed in the analysis of learning and evaluation of learning outcomes only planned the use of the lecturing method with one additional method, such as question and answer or assignment or discussion. In addition, in all learning activities listed in lesson plan for grade XI of Science program in the even semester, teacher 2 planned the use of student facilitator and explaining method. Whereas teacher 3 planned the use of problem solving/problem based learning method with cooperative learning strategies and variations in methods comprising of discussion, lectures, question and answer, and assignments in each learning.

Looking at the choice of models and learning methods listed and the lesson plan designed by the History teachers indeed showed the application of constructivist learning with a scientific approach. Unfortunately, the use of learning methods that tended to be similar, namely discussions varied with questions and answers, assignments, and lectures, had allowed the emergence of boredom in students in participating in learning activities. Teacher 1 was no exception, although more choices of learning models were operative in his learning process, but the core of the planned learning method was discussion activities. Ideally, History teachers should plan the use of learning models and methods through the analysis of learning methods that take into account the characteristics of the subject matter carefully [13].

The use of discussion methods varied with the lecture method, question and answer, and assignment seemed less rational. The use of methods that tended to be monotonous would lead to boredom in students and less efficient in time management. The implementation of the learning model and discussion method varied with the question and answer method, lecture, and assignment according to the learning syntax would not be completed on time. This was acknowledged by the three History teachers, stating that the learning activities were often not in accordance with the planned time allocation when each step of learning was carried out in accordance with the learning syntax listed in the lesson plan. In addition, the use of variations in the method of discussion, question and answer, assignment, and lectures indicated that the teacher had not fully implemented the student-centered learning activities. As explained by [14], the method of discussion, library research, role playing, social drama, and assignment included methods that were centered on students, while the lecture, question and answer, and training methods were the types of methods on which teachercentered.

\subsection{Instructional Media}

Learning media has an important role in History learning. The use of appropriate learning media will support learning strategies and methods to achieve learning objectives. The results of the analysis of the learning media components listed in the lesson plan showed that the instructional media planned by the teacher included visual and audio visual media. Visual media used included pictures of hero figures, maps, concept maps, and History books. Audio visual media included films/videos related to the material. The use of these media was supported by the use of instruments such as LCDs, laptops, internet and cell phones.

Planning the use of instructional media as mentioned above can be categorized according to the regulation, namely being able to support the implementation of constructivist learning with a scientific approach. The movement of learners was not limited to traditional media, but there was freedom to use technological sophistication such as accessing information through the internet network on mobile phones. Displaying videos or films related 
to material through laptops connected to the LCD helped students understand the material context learnt learned by listening, seeing, and analyzing learning object directly. The use of media like this without any variation with other media can also cause boredom, and it can even be too imposing, thus making the learning less relevant to the context of the material being studied. This could be seen in one of the lesson plans designed by teacher 3 who planned the use of audio visual media in the form of Bharatayuda story, while the material being studied was Hindu-Buddhist kingdoms and cultural heritage in Indonesia. In addition to being imposing, the use of media would also not be effective in helping students to understand the context of the material studied. However, in the area around the students there were sites, objects, and historical heritage buildings of the Hindu era which can be used as learning media.

Ideally the use of learning media can support the delivery of messages and the content of the material studied, regardless of the fact that the media was traditional or information technology based. Although based on advanced technology, but if the context of the media used is not appropriate with the content of the material, it will not be able to support the effectiveness of the achievement of learning objectives. In History learning, the use of appropriate learning media with specific content will influence and change traditional historical methods and learning [15]. Logically, no matter how sophisticated the media used in the learning process if the content is not right, the content will not influence and change traditional methods or History learning. Conversely, learning media that utilizes everything that is close to students, such as informant and the natural, social, and cultural environment that are directly related to material content, will influence the achievement of learning objectives. For examples, performing arts such as ketoprak, ludruk, and wayang orang, as well as visiting historical sites, historical tour, and performing oral or folklore traditions.

\subsection{Assessment}

The assessment procedures listed in the overall lesson plans were in accordance with the characteristics and assessment approaches in the 2013 curriculum in the Regulation of Ministry of Education and Culture No. 81A of 2013 concerning guidelines for the implementation of the 2013 curriculum. The assessment plans included aspects of attitudes, knowledge, and skills that included an assessment of students' learning processes and results using test and non-test assessment techniques. Test techniques were planned to assess aspects of knowledge, while aspects of attitudes and skills used non-test assessment techniques. In the aspect of attitude, each teacher planned an assessment through observation, self-assessment, assessment between students, and journals. Except for odd and even semester for grade XI of Science program, the lesson plan designed by teacher 2 only planned attitude assessment through observation. The assessment of aspects of knowledge was done using written tests, oral tests, and assignments. In the aspect of skills, each teacher planned an assessment of practice during discussion, products of which were in the form of papers and notes, and portfolios. In addition, each teacher included the minimum passing criteria of Kriteria Ketuntasan Minimun (KKM) that must be met by students both in each basic competence and the overall competence.

Each lesson plan had attached an assessment instrument covering aspects of attitudes, knowledge, and skills. However, each assessment instrument did not necessarily meet the principle of evaluation. The preparation of assessment instruments in each aspect seemed to operate important principles. This could be seen from the format of assessment instruments, content, and the use of languages that were less structured. First, this was evident on the attitude aspect. The choice of type of attitude aspect assessment included observation, self-assessment, assessment between students, and journals. Each teacher had attached an assessment type instrument selected in each lesson plan. In the same type of assessment, the format of the assessment instrument was not exactly the same, but it even tended to be different.

Second, the same issue was found on the aspect of knowledge. The types of questions that were the teacher's choice were related to a matter of description, multiple choice, or variation between the two. The number of item questions written in each lesson plan varied between 3 and 5 items for essay and 3 to 10 items for multiple choice questions. There were times when the number of items were less than the learning objectives. In some lesson plans, there were similar items even though the material topics were different, such as items in lesson plan 1, 3, and 4 for grade $\mathrm{X}$ of the even semester designed by teacher 1 . There were also a number of questions that did not match the number they should be, as in the lesson plan for grade XII of Science program of the odd semester, lesson plan 1, 
lesson plan 2, lesson plan 7, lesson plan 8, and lesson plan 9 for grade XII for Science program of the even semester, as well as lesson plan 1 and lesson plan 2 for grade XI of Science program of the even semester. The first three lesson plans planned 5 problem descriptions but only problems 3 and 2 were listed, while the other 5 lesson plans included 50 multiple choice questions, but only 3 questions were listed.

In addition, the contents of the items have not led to the expected abilities in the learning objectives. The operational verbs in the item (question words) used the words "mention", "explain", "what", "show", "describe", and "how" rather than ask "why", "make" , "Prove", and "analyze". Whereas in many learning objectives they used operational verbs "analyze" rather than "explain", "describe", "find", and "discuss". Likewise with the execution of the questions, in some lesson plans there were differences between the command and the contents of the questions, such as those in lesson plan 3 and lesson plan 12 for grade XI of Science program for the even semester. The instructions for questions in lesson plan 3 were meant to be multiple choices, but the contents of the questions were in the form of essay. On the contrary, in lesson plan 12 the instruction was working on an essay, but the contents of the question were multiple choices. Then in several other lesson plans, the teacher did not plan to give tests both oral and written, regardless of the planned assignments. The same thing was also found in the odd semester lesson plan 2 for grade XI of Science program, lesson plan 1 and lesson plan 3 for grade XII of Social science program of the odd semester.

The explanation illustrated that in the preparation of knowledge assessment instruments, the teachers lacked of attention to learning objectives. As a result, the knowledge assessment instrument planned by the teacher in each lesson plan was not in accordance with the learning objectives. When linked to the principle of assessment, the assessment had not been able to clearly measure the learning outcomes that had been determined in accordance with the learning objectives [16]. In addition, the use of operational verbs in item questions was more directed towards developing the ability of students to mention, identify, describe, and explain learning object, while operational verbs in learning objectives were more trying to develop analytical skills. These abilities when linked to Bloom's taxonomy, still include knowing cognitive abilities (C1), understanding (C2), and applying (C3) [8].
Furthermore, if it is related to the nature of History learning that seeks to develop critical thinking skills, then the instrument for assessing aspects of knowledge developed by the teacher is not appropriate because it is still related to memorization [12].

Third, issues were also related to aspects of skills. There was at least one type of skill aspect assessment in each lesson plan. This type of skill aspect assessment was the choice of each History teacher, including assessment of practice during discussions, products in the form of papers or written reports, projects in the form of assignments, and portfolios. In certain types of assessment sometimes the instrument format was exactly the same despite the different classes. The assessment was carried out during the learning process in the classroom through discussions and outside the classroom through assignments. Similar to the two previous assessment aspects, the preparation of an assessment of skills aspects also seemed to adhere to important principles and lacked of attention to the principles of assessment. This can be seen from the composition of the unstructured assessment format and unclear assessment criteria. In certain instruments, aspects of skills assessment still led to cognitive abilities and low-level skills. Of course this did not support the ultimate objectives of History learning that aimed to practice critical thinking skills.

\section{Conclusion}

The explanations above show that each teacher was aware that the lesson plan has a function as a guide for the implementation of learning. The composition of the lesson plan component had not referred to the provision of the new 2013 curriculum implementation process standard which is the Regulation of Ministry of Education and Culture No. 22 of 2016. The impact was demonstrated by the fact that the results of the suitability analysis of each lesson plan component of each teacher had not achieved an optimal score even though they either fell into the Good category or comply with the regulation and have reflected the application of the scientific approach. This condition indicated that teachers were less responsive to changes in government policies and hardly paid attention to the principles of preparing the lesson plans. To find out the root of the problems that caused such conditions to occur, it is necessary to conduct similar studies that seek to uncover the preparation of the history teacher learning tools. The number of similar studies 
will add input and clarify real conditions in schools, so that policy makers are encouraged to take policies that aim to improve or maintain the quality of learning based on the 2013 curriculum provisions, especially history learning.

\section{References}

[1] Aman. 2011. Model Evaluasi Pembelajaran Sejarah. Yogyakarta: Ombak

[2] Mulyana, A. 2012. Inovasi Pendidikan diawali dari Inovasi Pengembangan Rencana Pelaksanaan Pembelajaran. [Online]. Available: http://ainamulyana.blogspot.com/2012/inovasipendidikan-dapat-diawali-dari.html. [Accessed: Sept. 15, 2016].

[3] Creswell, John. 2015. Educational Research: Planning, Conducting, and Evaluating Quantitative and Qualitative. Pearson Education, Inc. Translated by Helly Prajitno Soetjipto dan Sri Mulyantini Soetjipto. 2015. Riset Pendidikan: Perencanaan, Pelaksanaan, dan Evaluasi Riset Kualitatif dan Kuantitatif. Yogyakarta: Pustaka Pelajar

[4] Miles, Matthew B dan A. Michael Huberman. Qualitatif Data Analysis. Sage Publication. Translated by Tjetjep Rohendi Rohidi. 1992. Analisis Data Kualitatif. Jakarta: UI Press

[5] Lincoln, Yvonna S dan Egon G. Guba. 1985. Naturalistic Inquiri. Newbury Park London: Sage Publication

[6] Saefuddin, H. Asis dan Ika Berdiati. 2015. Pembelajaran Efektif. Bandung: Remaja Rosdakarya

[7] Uno, Hamzah B. 2014. Perencanaan Pembelajaran. Jakarta: Bumi Aksara

[8] Anderson, Lorin W dan David R. Krathwohl. 2001. A Taxonomy for Learning, Teaching, and Assessing: A Revision of Bloo's Taxonomy of Educational Objectives. A Bridged Edition. Addision Wesley Company. Translated by Agung Prihantoro. 2010. Kerangka Landasan Untuk Pembelajaran, Pengajaran, dan
Assesmen: Revisi Taksonomy Pendidikan Bloom. Yogyakarta: Pustaka Pelajar

[9] Mulyasa, E. 2007. Kurikulum Tingkat Satuan Pendidikan. Bandung: Remaja Rosda Karya

[10]Susilo, M. J. 2007. Kurikulum Tingkat Satuan Pendidikan: Manajemen Pelaksanaan dan Kesiapan Sekolah Menyongsongnya. Yogyakarta: Pustaka Pelajar

[11]Fordham, Michael. 2012. Disiplinary History and The Situation of History Teacher. Education Sciences. Volume 2, December 2012. pp. 242-253. [Online]. Available: www.mdpi.com/journal/education. [Accessed: Oct. 6, 2016].

[12]Hasan, S. Hamid. 2012. Pendidikan Sejarah Indonesia: Isu dalam Ide dan Pembelajaran. Bandung:Rizqi Press

[13]Kemendikbud. 2014. Buku Pedoman Guru Mata Pelajaran Sejarah. Jakarta: Kemendikbud

[14]Suyono dan Hariyanto. 2015. Implementasi Belajar dan Pembelajaran. Bandung: Remaja Rosdakarya

[15]Adesote, F.A dan Fatoki O.R. 2013. The Role ICT in the Teaching and Learning of History in the $21^{\text {st }}$ Century. Academic Journal. Volume 8 (21), 10 November 2013. pp.2155-2159. [Online].

Available: www.academicjournals.org/ERR. [Accessed: Oct. 5, 2016].

[16]Purwanto, M. Ngalim. 2012. Prinsip-Prinsip dan Teknik Evaluasi Pengajaran. Bandung: Remaja Rosdakarya

\section{Author profile}

Agusningrum was accepted as agraduate student of social science study program at Faculty of Teacher Trainee and Education, Universuty of Jember in September 2015, and passed the desertation examination in January 4th, 2018.

Bambang Soepeno and Sumardi is lecture in social science study program at Faculty of Teacher Trainee and Education, Universuty of Jember. 